\title{
A Sustainable process by bio- scouring for cotton knitted fabric suitable for next generation
}

\begin{abstract}
Textile processing is a growing industry that traditionally has used a lot of water, energy and harsh chemicals. Bio-preparation is a developing and promising technique for lowering the consumption of chemicals specially in wet finishing where plenty of these compounds are used. The conventional scouring process involving the harsh environment is slowly being replaced with environment-friendly approach using enzymes. Enzymes are specific and fast in action and small amounts of enzyme often save large amounts of raw materials, chemicals, energy and water. In this study, samples of Cotton fabrics bio-scoured by Scourzyme L. and they were scoured conventionally. Then, they were dyed with reactive dyes in conventional methods. Samples were analyzed by reflective spectrophotometer, mechanical tester, and then compared. Such a process enhanced the absorbency of the fabric without appreciable strength loss and also helped in the proper dyeing and finishing of the fabric. The described enzymatic procedure is accompanied by a significant lower demand of energy, water, chemicals, time and therefore costs. It was found that the water absorbing character of the Bio scoured fabric was found to be considerably higher than that of the conventionally scoured fabric. Also, the tensile strength of the cotton fabric was found to be higher for the sample treated using Scourzyme L enzyme than the sample treated conventionally. So it has advantages as well in terms of ecology as in economy.
\end{abstract}

Keywords: bio-preparation, cotton fabric, enzyme treatment, dyeing, eco-friendly, cost saving
Volume 5 Issue I - 2019

\author{
Ummelewara Bristi,Ashikul Kabir Pias, \\ Ferdous Hossain Lavlu \\ Apparel Manufacturing \& Technology (AMT), BGMEA University \\ of Fashion \& Technology (BUFT), Bangladesh
}

\begin{abstract}
Correspondence: Ummelewara Bristi, Lecturer,Apparel Manufacturing \& Technology (AMT), BGMEA University of Fashion \& Technology (BUFT), Dhaka, Bangladesh, Tel 8801736107980,Email ummelewara@buft.edu.bd
\end{abstract}

Received: January 27, 2019 | Published: February 15, 2019

\section{Introduction}

Textile industry is now growing rapidly because of its eco-friendly environment and improving the requirement for textile industries to overcome the pollution. And now it's removed by the use of enzymes which require some chemical process of fibers. Enzymes mostly used now in the industry last 100 years.

Scouring is an important pre-treatment operation in the dispensation of cotton and cotton blended materials. The main objective of scouring is to remove the non-cellulosic ingredients of cotton fibre which make the fibre non-absorbent. Conventionally, scouring is done in a hot aqueous solution of $\mathrm{NaOH}$ to remove hydrophobic apparatuses from the primary wall (e.g. pectin, protein and organic acids) and the cuticle (waxes and fats). Enzymes in textile wet processing have added a new line research and likely eco-friendly substance to give a good solution to the problem of highly toxic chemicals causing environmental pollution.

Now a days, it is becoming important to consumers that the clothes they buy are well made and of high-quality material. Additionally, a growing number of consumers are also interested in clothes that are produced in an environmentally friendly way without the extensive use of harsh chemicals.

Untreated cotton contains various kinds of impurities, such as waxes, pectin's, hemi celluloses and mineral salts, present in the cuticle and primary cell wall of the fiber. ${ }^{1}$ The goal of the cotton preliminary process is the remove the hydrophobic and non-cellulosic components and produce highly absorbent fibers that can be dyed and finished uniformly. These are responsible for the hydrophobic possessions of raw cotton and interfere with aqueous chemical processes on cotton. Therefore, before cotton yarn or fabric can be dyed, it needs to be pretreated to take away materials that inhibit dye binding. This step, named scouring, expands the wettability of the fabric and normally uses alkalis, such as sodium hydroxide. However, these chemicals also attack the cellulose, leading to reduction in strength and loss of fabric weight. Furthermore, there salting waste water has a high COD (Chemical Oxygen Demand), BOD (Biological Oxygen Demand) and salt content. Enzyme reactor bio scouring, leaves the cellulose structure almost intact, preventing cellulose weight and strength loss. Bio scouring has a number of potential advantages over traditional scouring. It is lower BOD, COD, TDS (Total Dissolved Solids), performed at neutral $\mathrm{pH}$, which reduces total water consumption the treated yarn/fabrics retain their strength properties, the weight loss is reduced or limited compared with processing in traditional ways, and it increases cotton fiber softness. Several types of enzyme, including pectinases, cellulases, ${ }^{2}$ proteases, ${ }^{3}$ and lipases/cutinizes, alone or combined ${ }^{4}$ have been studied for cotton bio scouring, with pectinases be the most effective.

It has become an essential demand for the mill managers to sort out an alternative for the traditional caustic scouring process for some of its unavoidable limitations:

In traditional scouring process caustic soda causes damage to the fiber and its strength as well. Because, caustic works on swelling method and attacks the secondary cell wall being almost pure cellulose.

In practice, weight loss is around $8-12 \%$ which means an excessive loss of fabric weight unnecessarily. While, the recommended weight loss for caustic scouring is $3-8 \%$. It should not be accepted.

As caustic works on swelling method by which all the necessary and unnecessary particles are removed from cotton fiber and most importantly it damages the actual structure of cotton fiber, it inspires the dye molecules not to fix according to our requirements and it causes a significant amount of dye loss. 
In caustic scouring it takes around $95^{\circ} \mathrm{C}$ temperature. To raise and lower the temperature at this degree it requires a huge amount of energy on which sector we are struggling and it takes more time which reduces the productivity.

Caustic scouring needs several rinsing steps which increase the demand of amount of water volume and a high $\mathrm{pH}$ range (12-14), it needs to neutralize the scouring bath for the processes ahead.

A lot of harsh chemicals are used in traditional scouring process which is very much responsible to increase the amount of BOD, COD and TDS in the effluent water and increase the unwanted pressure on environment. Caustic scouring is responsible for the lion parts of the total effluent of a factory. It produces:

a. $54 \%$ to the total BOD

b. $49 \%$ to the total COD

c. $10-20 \%$ of the total pollution load generated during entire textile processing operation.

In traditional scouring, the longevity of the workers is badly affected by the handling of these harsh chemicals. The handling of harsh chemicals increases the possibilities of accident

\section{Literature review}

Cotton is a delicate fiber that develops around the seeds of the cotton plant. The fiber is regularly spun into string and used to make a delicate, breathable material. Cotton is an important product in light of the fact that just about $10 \%$ of the crude weight is lost in preparing. When hints of wax, protein, and so forth are expelled, the rest of a characteristic polymer of unadulterated cellulose. This cellulose is orchestrated such that gives cotton one of a kind property of solidarity, strength, and permeabilizes. The layers in the cell structure are, from the outside of the fiber to the inside, cuticle, primary wall, secondary wall, and lumen. These layers are different structurally and chemically. ${ }^{7}$ The primary and secondary walls have different degrees of crystalline, as well as different molecular chain orientations. The cuticle, composed of wax, proteins and pectin's is $2.5 \%$ of the fiber weight and is amorphous. The primary wall is $2.5 \%$ of the fiber weight, has a crystallinity index of $30 \%$, index of $70 \%$, and is composed of cellulose. The lumen is composed of protoplasmic residues. ${ }^{6}$ Cotton fibers' have a fibrillar structure. The whole cotton fiber contains 88 to $96.5 \%$ of cellulose, the rest are non-cellulosic polysaccharides constituting up to $10 \%$ of the total fiber weight. ${ }^{7}$ Every fiber is comprised of twenty to thirty layers of cellulose curled in a perfect arrangement of regular springs. At the point when the cotton boll (seed case) is opened the filaments dry into level, bent, strip like shapes and move toward becoming crimped together and interlocked. This interlocked shape is perfect for turning into a fine yarn.

Cotton is made out of unadulterated cellulose, a normally happening polymer. Cellulose is a starch, and the particle is a long chain of glucose (sugar) atoms.

Today cotton is created in numerous parts of the world, including Europe, Asia, Africa, the Americas and Australia, utilizing cotton plants that have been specifically reared with the goal that each plant develops more fiber. In 2002, cotton was developed on $330,000 \mathrm{~km}^{2}$ of farmland. 47billion pounds (21million t) of crude cotton worth 20billion dollars US was developed that year.
The cotton business depends intensely on synthetic substances, for example, composts and bug sprays, albeit a few ranchers are moving towards a natural model of generation, and concoction free natural cotton items are presently accessible. Generally, a standout amongst the most financially ruinous vermin in cotton generation has been the boll weevil.

Most cotton is collected mechanically, either by a cotton picker, a machine that expels the cotton from the boll without harming the cotton plant, or by a cotton stripper which peels the whole boll off the plant. Cotton strippers are commonly utilized in areas where it is too blustery to even think about growing picker assortments of cotton and by and large utilized after use of a defoliant or normal defoliation happening after a stop. Cotton is a perpetual product in the tropics and without defoliation or solidifying, the plant will keep on developing. Cotton is a nearby relative of okra and hibiscus.

The general state of knowledge of the chemical composition of a mature cotton fiber is presented in Table 1.

Table I Typical values for the composition of a Mature Dry Cotton Fiber

\begin{tabular}{ll}
\hline Constituent & Percentage \\
\hline Cellulose & $94 \%$ \\
Pectin & $1.20 \%$ \\
Protein & $1.30 \%$ \\
Wax & $0.60 \%$ \\
Mineral Matters & $1.20 \%$ \\
Other Substances & $1.60 \%$
\end{tabular}

Table 1 demonstrates that non-cellulosic materials represent just a little measure of the fiber weight. These materials are formless and are situated in the fingernail skin and the lumen. The fingernail skin frames a defensive layer to shield the cotton from ecological assaults and water entrance the Waxy materials are chiefly in charge of the non-spongy qualities of crude cotton. Gelatins may likewise ha ve an impact, since $85 \%$ of the carboxyl gatherings in the gelatins are methylated. ${ }^{8}$ Crude cotton filaments need to experience a few compound procedures to get properties reasonable for use with scouring, non-cellulose substances (wax, gelatin, proteins and hemicelluloses that encompass the fiber cellulose center are expelled, and thus, strands wind up hydrophilic and appropriate for fading, coloring and other preparing. By expelling gelatin, it is simpler to evacuate all other non-cellulosic substances. The procedures of bioscouring that are being used today depend on the decay of gelatin by the proteins called pectinase.

Enzymes are organic impetuses that quicken the speed of artificial responses. Within the bio scouring method temperature and $\mathrm{pH}$ is crucial parameters for an honest outcome. A gentle $\mathrm{pH}$ and temperature offer U.S.A. the foremost ideal outcome. All Enzymes are fabricated from macromolecule and those them every have a quite sure threedimensional form. The form is various for each macromolecule and each compound simply takes a trial at one substance or quite artificial response for instance enzyme accelerates the breakdown of starch into the sugar disaccharide. Enzyme accelerates the breakdown of oxide. The aim behind this is often the substrate fits into associate degree exceptional space of the compound known as the dynamic website. The response happens with lower feat vitality that is come back to by shaping a middle of the road chemical substrate. Later the substrate 
particle is modified over into the item and also the catalyst itself is recovered. Enzymes are high relative atomic mass proteins that are created by living beings. Within the response itself the proteins aren't spent, they do not become a bit of the last results of their activity, nevertheless simply amendment the artificial obligations of various mixes. Once the response is finished, the compound is discharged yet again, ready to start another response. The customary scouring method together with the unforgiving condition is bit by bit being supplanted with condition agreeable methodology utilizing catalysts. Proteins are specific and fast in world and tiny measures of compound frequently spare plenty of crude materials, artificial Enzymes, vitality and water (9) generally most catalysts are used only once and disposed of once their chemical activity. Proteins will work on air weight and in light conditions regarding temperature and causticity $(\mathrm{pH})$. Most Enzymes work ideally at a temperature of $30^{\circ} \mathrm{C}-70^{\circ} \mathrm{C}$ and at $\mathrm{pH}$ esteems, that are purpose of $\}$ the unbiased point $(\mathrm{pH} 7)$. Macromolecule forms are probably vitality economical and spare golf shot resources into distinctive hardware impervious to heat, weight or erosion. Attributable to their proficiency, specific activity, the light conditions within which they work and their high biodegradability, Enzymes are exceptionally acceptable for a large scope of contemporary applications. Proteins are used within the material business since they quicken responses, act simply on specific substrates, and work below light conditions, are protected and straightforward to regulate, will come after unforgiving synthetics and are perishable. ${ }^{9}$ Business wellsprings of chemicals are gotten from 3 essential sources, i.e., creature tissue, plants and organisms. These ordinarily happening chemicals are frequently not promptly accessible in adequate amounts for sustenance applications or mechanical use. Business amounts are gotten by disengaging microorganism strains that deliver the perfect chemical and advancing the conditions for development. This methodology, for certain understood for over three, 000 years, is named maturation. many techniques, for instance, submerged maturation $(\mathrm{SmF})$, sturdy state aging (SSF) and whole cell immobilization are effectively used for compound generation from va for all the way down to earth applications, immobilization of microorganisms on sturdy materials offers many focal points, together with rehashed use of chemical, simplicity of item partition and improvement of catalyst steadiness. ${ }^{10}$ Today, this aging procedure is completed during a holder vessel. Once maturation is finished, the microorganisms are crushed; the catalysts are disengaged, and more ready for business use. Chemical manufacturers produce Enzymes as per all pertinent legislative controls. an oversized portion of the mechanical Enzymes are created by a usually number of microorganism hosts like genus Aspergillus and Trichoderma parasites, actinomycete organisms imperfect and Bacillus microorganisms. Catalysts are ordered by the mixes they follow up on: pectinases that separate pectin's, proteases that separate proteins, celluloses that separate polyose, lipases that split fats (lipids) into glycerin and unsaturated fats, and amylases that separate starch into basic sugars. Major styles of enzymes utilized in the textile business and their application are given.

Moreover, cellulases, pectinases, hemicelluloses, lipases and catalases are utilized in totally different cotton pre-treatment and finishing processes. Cellulase enzymes were 1st introduced once decades of enzyme usage as associate degree business customary for de sizing processes. Today, efforts among the textile business appear to specialize in substitution ancient natural-fiber scouring processes with enzyme-based solutions. Because the purpose of scouring is to get rid of natural impurities like compound substances like pectin's, waxes and xyloma nans, among different from cotton or other natural fibers, there are many accelerators that may act on such impurities. Alkaline pectinases that loosens fiber structure by removing pectin's between polyose fibrils and eases the wash-off of waxy impurities, is that the key accelerator for a bio-scouring method. Different enzymes together with cellulases, hemi cellulases, proteases and lipases are tested, however nowadays, the sole business bio scouring accelerator product ar supported pectinases. Associate degree economical bio preparation method ought to be supported a mix, ideally at the same time, of enzymes for de sizing, scouring and bleaching in one tub. Success in developing such a method would lead to a straightforward method, together with savings in water, time and energy consumption. Compared to standard alkaline boiling off, the benefits of bio scouring ar obvious that it will save water and time by reducing one rinse cycle: save energy by lowering the treatment temperature from boiling to around 50-60? Can allow less fiber weight loss and fewer COD and physical structure within the effluent. The novel accelerator permits for the system to perform at a lot of lower temperatures for bleaching and at neutral $\mathrm{pH}$ levels (Table 2).

Table 2 Major types of enzymes \& their functions

\begin{tabular}{ll}
\hline Types of enzymes & Functions \\
\hline Pectinase & Breaks down pectin's in scouring (Bio-scouring) \\
Amylase & $\begin{array}{l}\text { To decompose starches applied in sizing (Bio-de sizing) } \\
\text { Breaks down cellulosic chains to remove protruding fibers by degrading \& create wash-down effect by surface } \\
\text { etching on denims (Bio-denim washing) }\end{array}$ \\
Lellulase & $\begin{array}{l}\text { Elimination of natural triglycerides (in scouring) or present in De sizing (tallow compounds) } \\
\text { Proteases }\end{array}$ \\
\hline
\end{tabular}

Moreover, cellulases, pectinases, hemicelluloses, lipases and catalases are used in different cotton pre-treatment and finishing processes. Cellulase enzymes were first introduced after decades of amylase usage as an industry standard for de sizing processes. Today, efforts within the textile industry seem to focus on replacing traditional natural-fiber scouring processes with enzyme-based solutions. As the purpose of scouring is to remove natural impurities such as polymeric substances like pectin's, waxes and xyloma nans, among others from cotton or other natural fibers, there are plenty of enzyme that can act on such impurities. Alkaline pectinases, which loosens fiber structure by removing pectin's between cellulose fibrils and eases the washoff of waxy impurities, is the key enzyme for a bio-scouring process. Other enzymes including cellulases, hemi cellulases, proteases and lipases have been tested, but at present, the only commercial bio scouring enzyme products are based on pectinases. An efficient bio preparation process should be based on a combination, preferably simultaneously, of enzymes for de sizing, scouring and bleaching in one bath. Success in developing such a process would result in a simple 
process, including savings in water, time and energy consumption. Compared to conventional alkaline boiling off, the advantages of bio scouring are obvious that it can save water and time by reducing one rinsing cycle: save energy by lowering the treatment temperature from boiling to around $50-60^{\circ} \mathrm{C}$ and permit less fiber weight loss and less COD and BOD in the effluent. The novel enzyme allows for the system to perform at much lower temperatures for bleaching and at neutral $\mathrm{pH}$ levels.

Textile process has benefited greatly in each environmental impact and merchandise quality over the utilization of enzymes. From the 7000 enzymes famed, solely concerning seventy-five are normally utilized in textile business processes. The principal enzymes applied in textile business are hydrolases (amylases, celluloses, proteases, pectinases and lipases/esterase's) and oxidoreductases (catalases). Amylases are still wont to take away starch-based sizes from materials once weaving. Cellulases are utilized to enzymatically take away fibrils and fuzz fibers, and have additionally effectively been introduced to the cotton textile business to provide the aged look of denim and different clothes. Proteases were assessed for the removal of wool fiber scales, leading to improved anti-felting behavior. Esterase's are with success studied for the partial reaction of fiber surfaces, up their hydrophilicity and aiding more finishing steps. Catalases are wont to take away $\mathrm{H}_{2} \mathrm{O}_{2}$ once bleaching, reducing water consumption.

The bio-scouring method is constructed on peptidase, pectinase and enzyme enzymes that act on proteins, pectin's and natural waxes to result scouring of cotton. Blessings of bio-scouring:

i. Milder conditions of process, low consumption of utilities, wonderful permeableness in merchandise.

ii. No oxy-cellulose formation and less strength loss attributable to absence of serious alkali in tub.

iii. Uniform removal of waxes ends up in higher levelness in coloring.

iv. Extremely appropriate for scouring of blends like silk, wool, viscose, modal, lyocel, and Lycra etc.

v. Low TDS in discharge.

vi. Material is softer and fluffier than typical scouring, ideal for terry towel/knitted merchandise.

The integrated Bio-de sizing associate degreed Bio-scouring system uses a through empirical observation developed accelerator formulation, supported enzyme, pectinase, peptidase and enzyme that act synergistically, leading to American state filler and scouring of cotton merchandise, below delicate circumstances.

\section{Methods and materials}

In the experiment, we've got used a Substrate of 100 percent gray cotton (knitted material textile \} in 220 GSM fabric we tend to receive from Northan fashion ltd, Tongi basic. We tend to used scourzyme L for scouring method $(\mathrm{NaOH})$, Detergent, Sequestering Agent, Wetting Agent/Non-ionic surfactants, Reactive dyes, Soda ash, Glauber salt chemical are use additionally. For cloth testing, we've got to required Instruments of photometer, Crock meter \& Crock fiber, Multi fiber equipment.

\section{Experimental works}

Materials: A hundred \% Cotton cloth having 220 GSM was utilized in this experiment that was received from Northan Tosrifa Ltd
Material preparation: A single jersey Cotton cloth having GSM 220 was kindly provided from Northan Tosrifa cluster Ltd that consists of dirt, dust, oil, wax etc. we've got taken samples from it every consideration ten grams. Before the scouring treatment the substrate was washed in refined water to extract the soluble constituents and so dried in Laboratory kitchen appliance. Once laundry and drying the kitchen appliance dry weight of the samples was restrained in an electrical balance.

The materials foremost eroded with accelerator named Scour accelerator additional $3-5 \mathrm{~g} / 1$ consistent with the formula in presence of $\mathrm{pH}$ five. 5 at $60^{\circ} \mathrm{C}$ minutes \& liquor magnitude relation was 1:20. The analysis of the scouring result was performed by the water perm ableness and also the weight loss of the materials as a result of the protein method. Coloring experiments to gauge the result of the scouring was applied with Reactive dye (Reactive Red) for two shade, at $60^{\circ} \mathrm{C}$ for forty $\min \&$ liquor magnitude relation was $1: 15$.

The materials were eroded by victimization chemical agent, $\mathrm{NaOH}$, Sequestering Agent, Detergent within the Scouring method. it absolutely was applied for hour at $95^{\circ} \mathrm{C}$ at a liquor magnitude relation of 1:20. Then colored with Reactive Dye (Reactive red) for two shades at $60^{\circ} \mathrm{C}$ minutes. Liquor was $1: 15$.

After the completion of the bio-scouring method the samples were washed with plight. Then the samples were treated with carboxylic acid and washed with cold water and squeezed properly. Then the laboratory kitchen appliance was used for drying the samples. Once laundry and drying the kitchen appliance dry weight of the bio-scoured samples was measured with the assistance of an electrical Balance.

\section{Fabric testing $\&$ analysis}

Whiteness index: The values for the white index (WI) was measured on a remission photometer, Spectra flash SF600X (Datacolor, USA), victimisation the CIE methodology, consistent with nut ISO 105-J02:1997(E). Every sample was closed double to provide associate degree opaque sample with four plies, and also the white was measured 10 times at totally different surfaces.

Percentage of weight loss: Weight loss of the sample was analyzed through the distinction between the material before and once protein treatment. Once treatment, material was dried, weighed and so weight loss decided as below:

$\mathrm{A}=$ (weight of the sample before scouring-weight of the sample once scouring)/(weight of the sample before scouring) $100 \%$

Drop Test: In this time, check was taken to soak up a colored drop on the material are measured that color drop comes from an answer of zero. $1 \%$ reactive red dyes. The form of the drop was discovered and also the time to soak up the drop was measured.

Wicking test: A cotton material strip $(18 \mathrm{~cm} 5 \mathrm{~cm})$ was suspended higher than the $\mathrm{H} 2 \mathrm{O}$ surface during a glass beaker such the horizontal bottom edge touches the surface of the water. A spontaneous wicking was discovered thanks to capillary force. The peak of the liquid rise boundary was recorded for five, 10,15,20,25,30 minutes.

Rubbing test: We did the rubbing check by Dry and we tend to strategies. In we tend to rubbing we wet the rubbing fabric consistent with check methodology and provide rating by scrutiny the Staining with the grey scale.

Similarly, for dry rubbing we tend to check the rubbing with dry rubbing fabric and compare the staining with grey scale for ratings. 
Color Fastness to rubbing may be a main check that is usually needed for each colored material either it's written or colored.

If the color fastness to rubbing is nice then its different properties like laundry fastness and sturdiness etc. improves mechanically as a result of the rubbing may be a methodology to see the fixation of the color on the material. So, if the fixation, it's rubbing properties are good.

Moisture regain test: Moisture Regain is well-defined because the weight of water during a material expressed a share of the kitchen appliance dried weight of the fabric.

At first, the material was kitchen appliance dried in 220c for two hrs. Then, the burden of the material was measured. Then, the material was unbroken during an accustomed atmosphere for twenty-four hrs. Again, the burden of the material was measured.

Let,

Oven dried weight of the fabric $=\mathrm{D}$
Weight of water in the fabric $=\mathrm{W}$

Moisture Regain, $R=\frac{W}{D} \times 100$

\section{Result and discussion}

\section{Absorbency test}

Wicking test: In this test, we have observed that for $3 \mathrm{~g} / \mathrm{l}$ caustic soda treated sample the wicking height was $8 \mathrm{~cm}, 1.3 \mathrm{~cm}, 0.8 \mathrm{~cm}, 0.5 \mathrm{~cm}$, $0.25 \mathrm{~cm}, 0.2 \mathrm{~cm}$ and for $4 \mathrm{~g} / 1$ caustic soda treated sample the wicking height was $8.3 \mathrm{~cm}, 1.5 \mathrm{~cm}, 1.2 \mathrm{~cm}, 0.6 \mathrm{~cm}, 0.4 \mathrm{~cm}, 0.3 \mathrm{~cm}$. and for $5 \mathrm{~g} / 1$ caustic soda treated sample the wicking height was $8 \mathrm{~cm}, 1.2 \mathrm{~cm}$, $0.9 \mathrm{~cm}, 0.6 \mathrm{~cm}, 0.3 \mathrm{~cm}, 0.2 \mathrm{~cm}$ after $5,10,15,20,25,30$ min respectively.

In this test, we have observed that for $3 \mathrm{~g} / \mathrm{l}$ bio scoured sample the wicking height was $6 \mathrm{~cm}, 2 \mathrm{~cm}, 2 \mathrm{~cm}, 1.3 \mathrm{~cm}, 0.8 \mathrm{~cm}, 0.8 \mathrm{~cm}$ and for $4 \mathrm{~g} / 1$ bio scoured sample the wicking height was $8 \mathrm{~cm}, 2.4 \mathrm{~cm}, 1.2 \mathrm{~cm}, 1.2 \mathrm{~cm}$, $0.8 \mathrm{~cm}, 0.6 \mathrm{~cm}$. and for $5 \mathrm{~g} / 1$ bio scoured sample the wicking height was $8.3 \mathrm{~cm}, 2.7 \mathrm{~cm}, 1.4 \mathrm{~cm}, 1.3 \mathrm{~cm}, 1.3 \mathrm{~cm}, 0.8 \mathrm{~cm}$ after $5,10,15,20,25,30$ min respectively (Figure 1) (Figure 2).
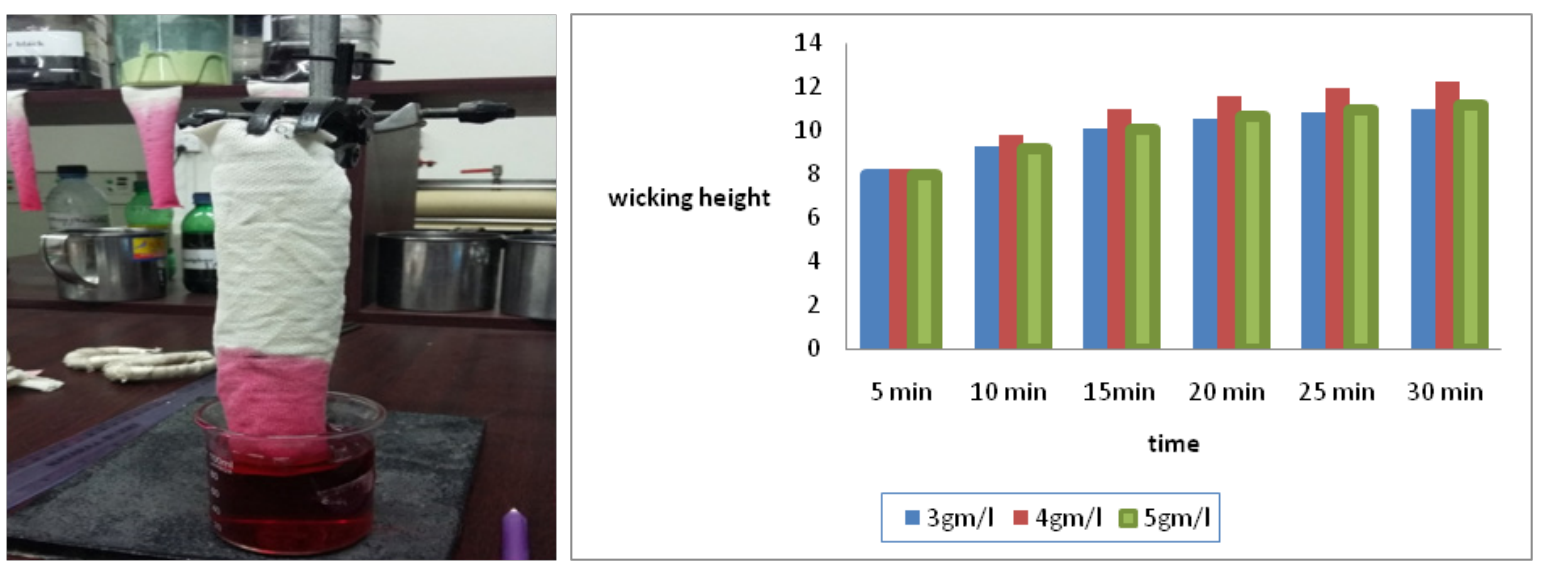

Figure I Vertical Wicking Test of Conventional Scouring.
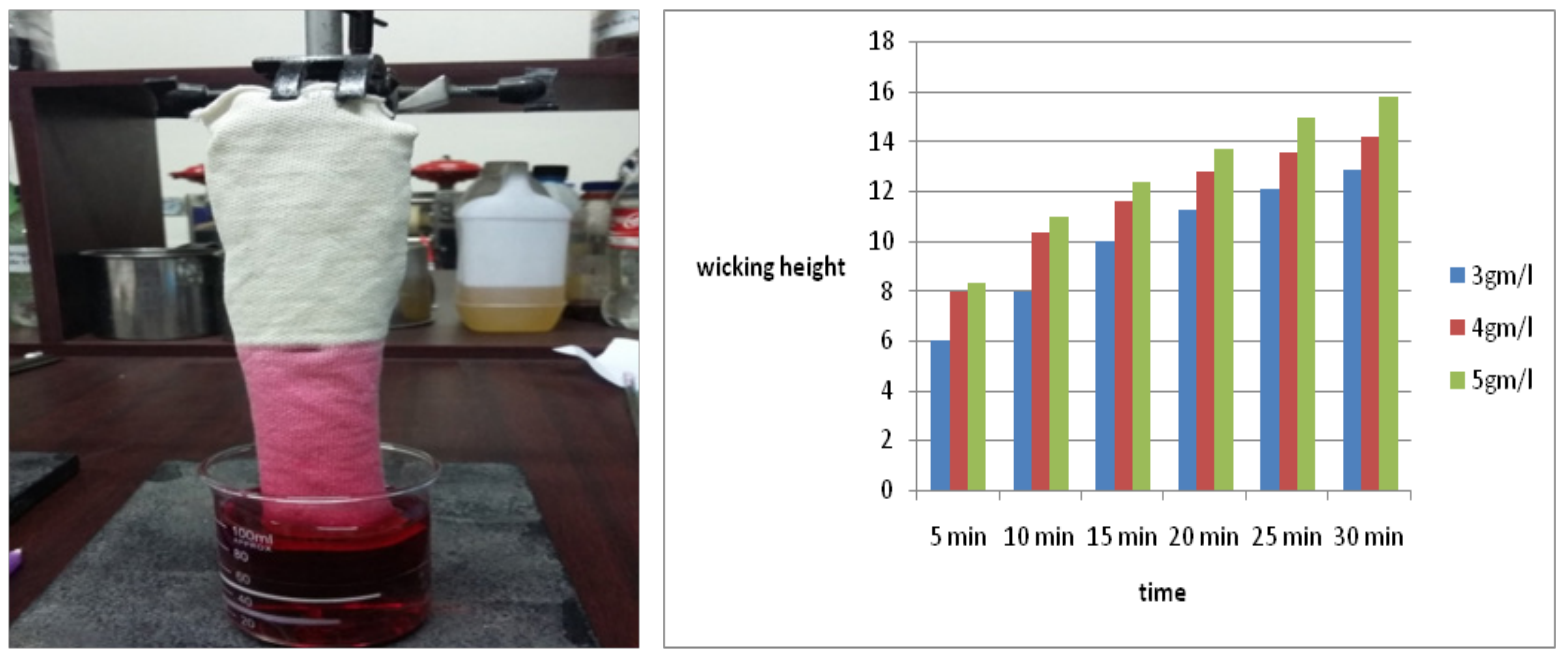

Figure 2 Vertical Wicking Test of Bio-Scouring.

Among this test results we have found that for $4 \mathrm{gm} / 1$, the absorbency of the fabric is most consistent. That's why we took $4 \mathrm{gm} / 1$ concentration of $\mathrm{NaOH}$ / Enzyme for further procedures.

Drop test: In this test, for Conventional sample, time to absorb the colored drop was $0.4,0.4,0.5 \mathrm{sec}$ for $3 \mathrm{~g} / \mathrm{l}, 4 \mathrm{~g} / \mathrm{l}, 5 \mathrm{~g} / 1$ respectively (Figure 3).

For Bio-Scouring sample time to absorb the colored drop was 0.2 , $0.4,0.5 \mathrm{sec}$ for $3 \mathrm{~g} / 1,4 \mathrm{~g} / 1,5 \mathrm{~g} / 1$ respectively (Figure 4) (Figure 5). 


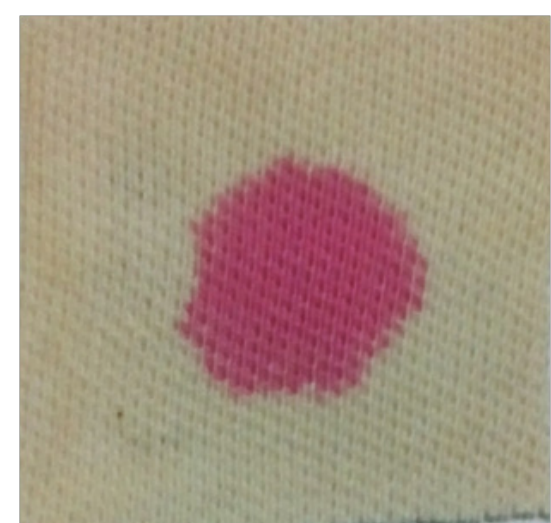

Figure 3 Drop test of conventional scouring.

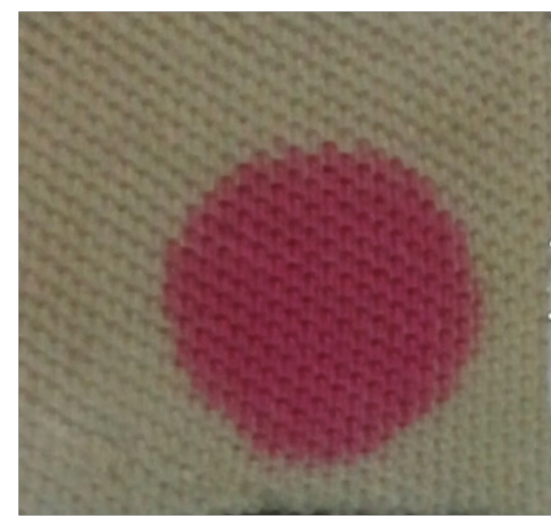

Figure 4 Drop test of bio-scouring.

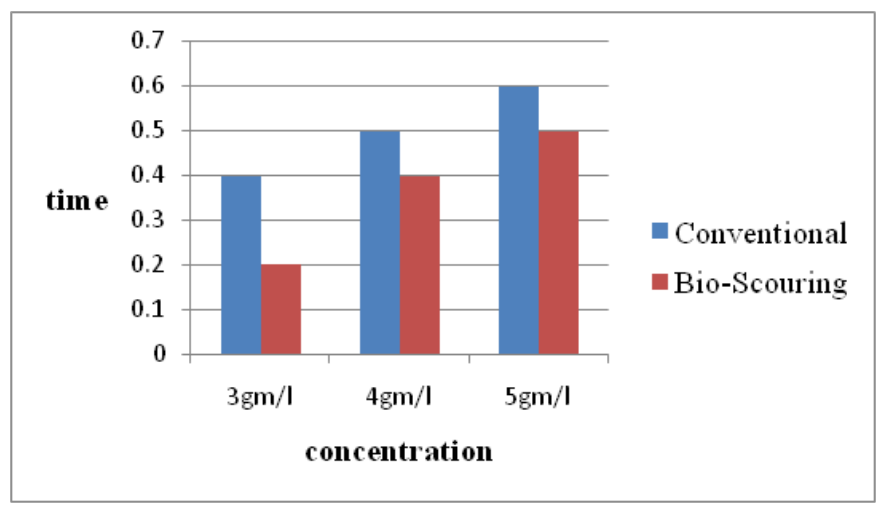

Figure 5 Drop Test of Bio-Scouring \& conventional.

Weight loss test: In this test, we have found that for caustic scouring the weight loss was $6.26 \%, 6.18 \%, 6.18 \%$ for $3 \mathrm{~g} / \mathrm{l}, 4 \mathrm{~g} / \mathrm{l}, 5 \mathrm{~g} / \mathrm{l}$ respectively.

In this test, we have found that for bio scouring the weight loss was $7.5 \%, 7.5 \%, 7.5 \%$ for $3 \mathrm{~g} / 1,4 \mathrm{~g} / \mathrm{l}, 5 \mathrm{~g} / 1$ respectively.

Whiteness index: For caustic scoured whiteness index is $36.84,40.55,40.11$ for $3 \mathrm{~g} / 1,4 \mathrm{~g} / 1,5 \mathrm{~g} / 1$ respectively and for Bio- scoured whiteness index is $11.64,17.56,12.29$ for $3 \mathrm{~g} / 1,4 \mathrm{~g} / 1,5 \mathrm{~g} / 1$ respectively.

For Grey Fabric STD WI are 5.34 (Figure 6).

\section{pH value}

pH value for conventional: For caustic scouring $\mathrm{pH}$ value was 10.5 (Figure 7).

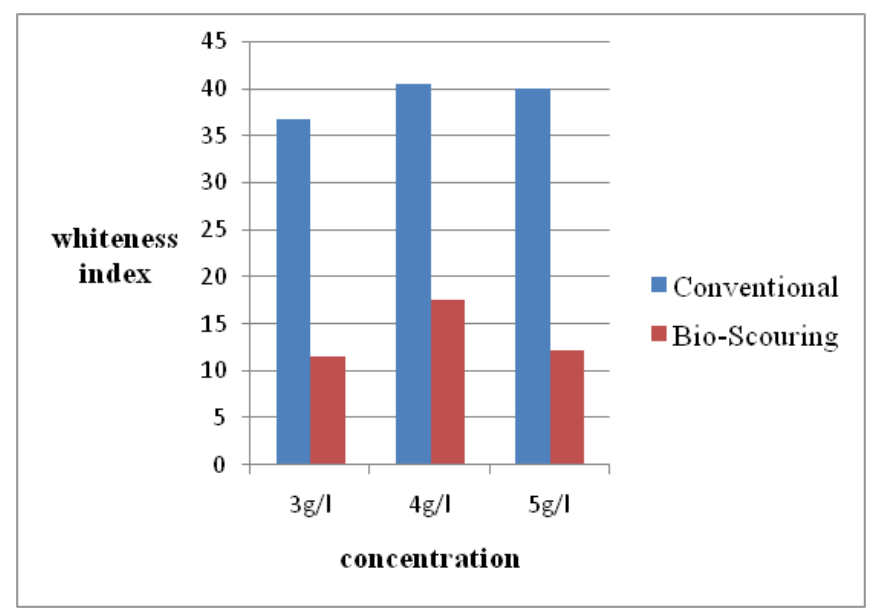

Figure 6 Whiteness index.

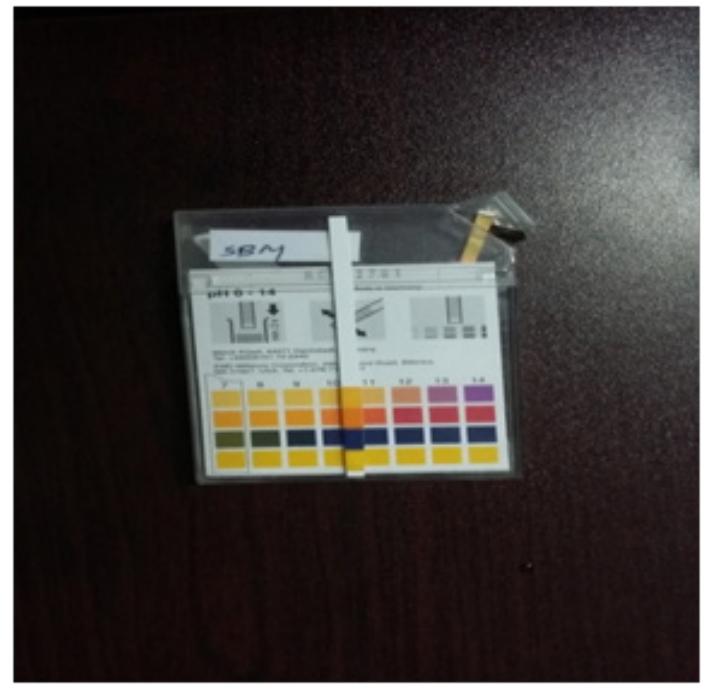

Figure $7 \mathrm{pH}$ value of conventional scouring.

pH value for bio-scouring: For Bio-scouring the value was 5.5 (Figure 8).

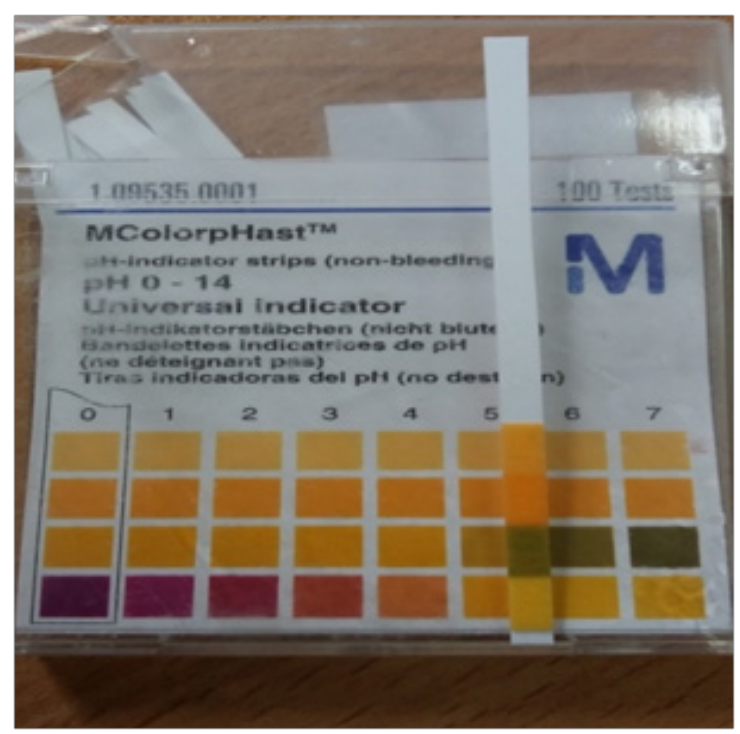

Figure $8 \mathrm{pH}$ value of Bio-Scouring. 
Colorfastness to wash: For Conventional scouring dry rub grade is 4-5 \& wet rub grade is $4-5$ according to the grey scale (Figure 9).

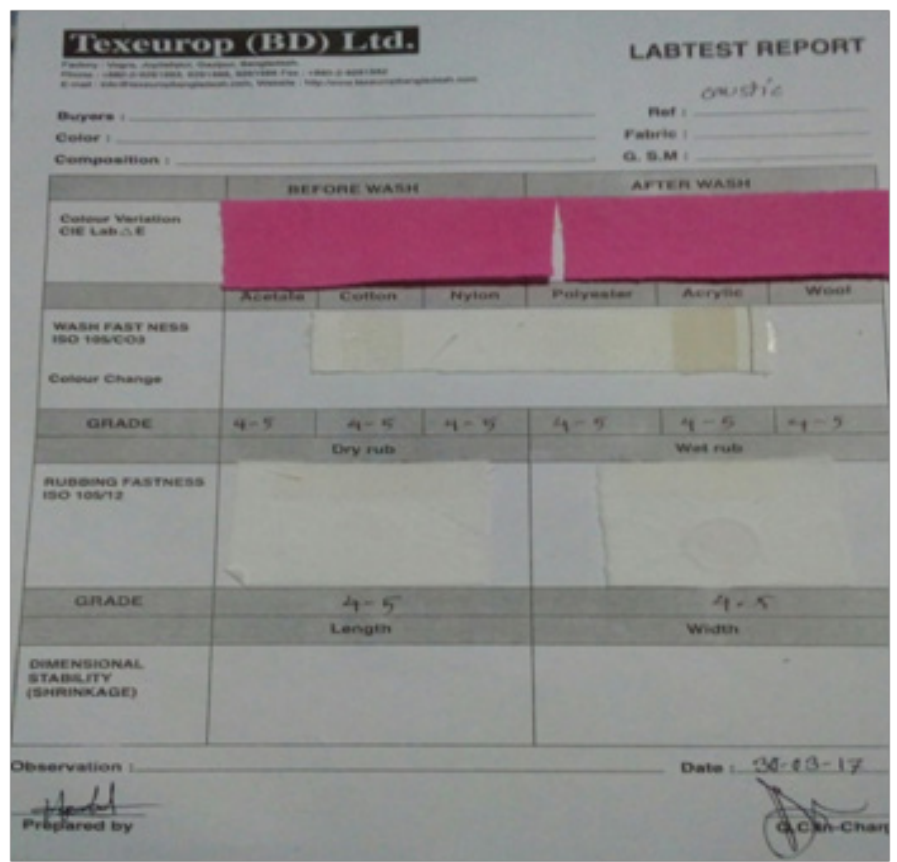

Figure 9 Colorfastness to wash for caustic scouring.

For Bio-Scouring dry rub grade is $4-5 \&$ wet rub grade is $4-5$ according to the grey scale (Figure 10).

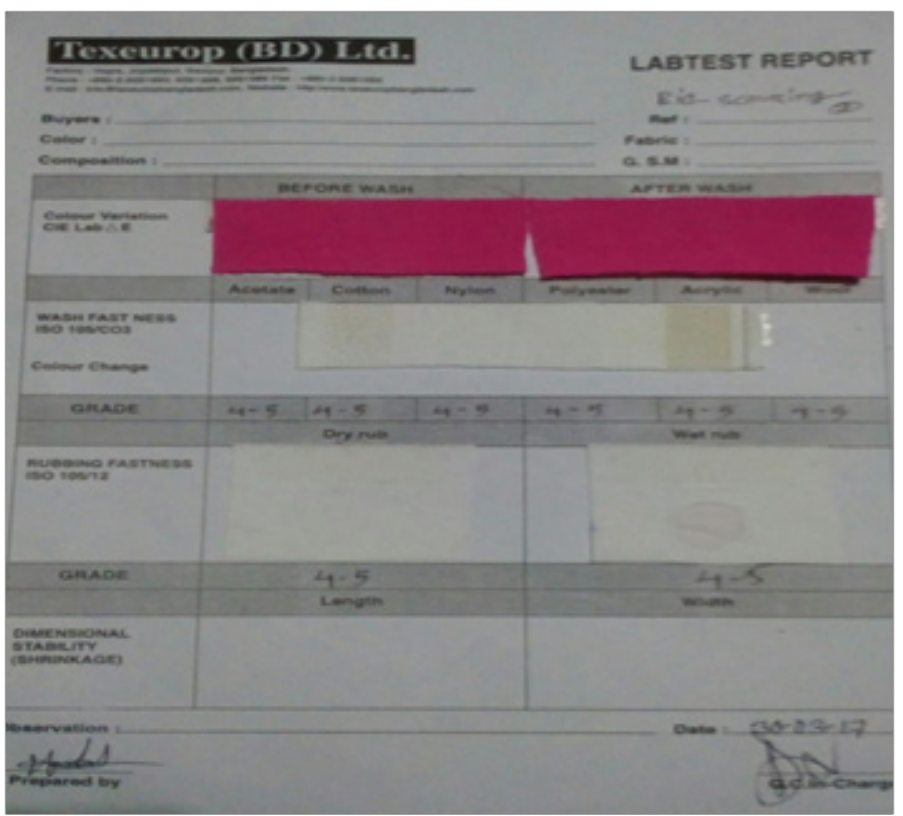

Figure 10 Colorfastness to wash test for bio scouring.

Moisture regain test: For Conventionally scoured Fabric Moisture Regain is $6.27 \%$ and for Bio-Scoured Fabric Moisture Regain is $6.78 \%$ (Figure 11).

\section{Dyed fabrics}

(Figure 12) (Figure 13)

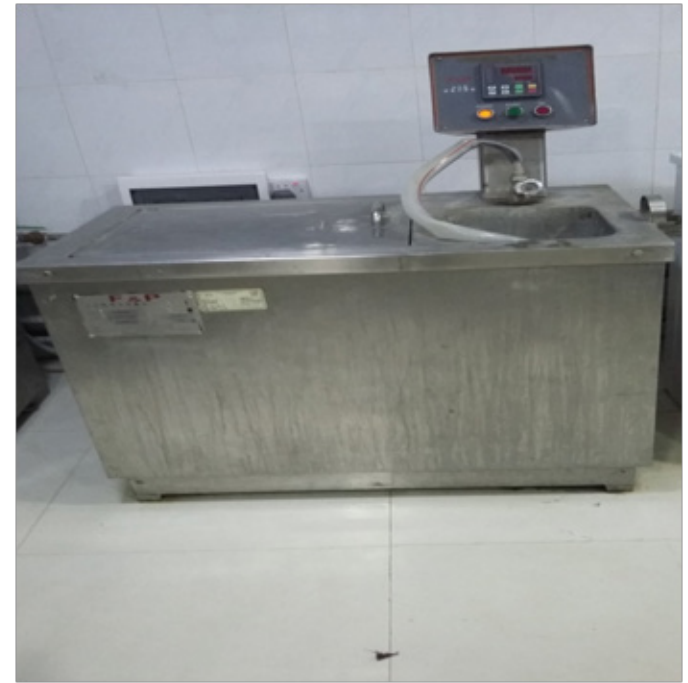

Figure II Color Fastness to wash test $\mathrm{m} / \mathrm{c}$.

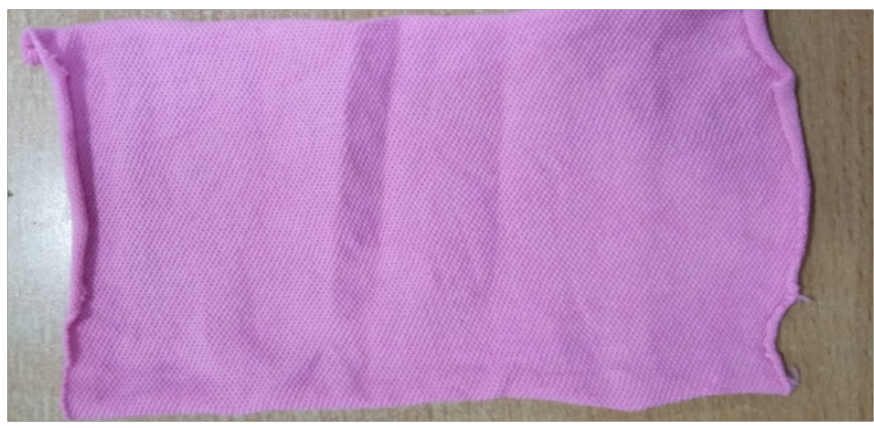

Figure 12 Conventionally Scoured Dyed Fabric.

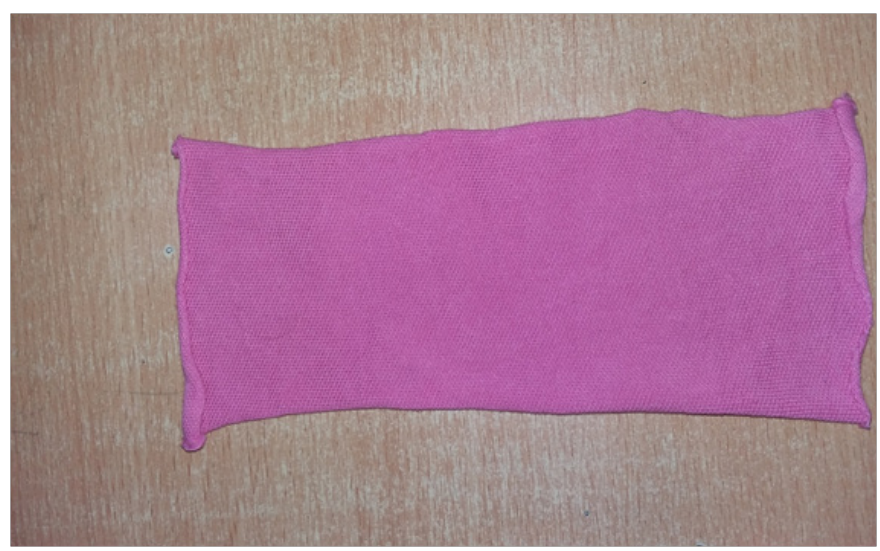

Figure 13 Bio-Scoured Dyed Fabrics.

\section{Conclusion}

The textile industry was recognized as a key sector where opportunities accessible from adapting biotechnology are high but current awareness of biotechnology is low. In textile processing the enzyme can be effectively used for introductory process like de sizing, scouring and bleaching.

Bio scouring can be suggested as an adequate procedure for scouring of cotton. It is a simple, repeat able and safe process. The 
removal of pectin components from cotton adequately improves the water absorbencies of the fibers and facilitates the penetration of the dye and other ingredients into the fiber. Natural qualities of the cotton fiber are preserved; the fabric is easier to the touch than after classic scouring. Fibers are also less damaged. These are just a few submissions of Biotechnology; however, much such potential are yet to be explored. Enzymes are not only beneficial from ecological point of view but they are also saving lot of change by reducing water and energy consumption which ultimately reduce the cost of production. It seems that in the future it will be possible to do every process using enzymes. Enzyme manufacturing companies constantly improve their products for more flexible application conditions and a more widespread use. The main hindrance in using enzymes is their high rate. If their cost can be managed, enzymes can be put to use in a much bigger way for textile dispensation applications.

\section{Future directions}

The possibility of leveraging inventions over industries could lead to new prospects for bio-based textile processes. Enzymes can be used in order to develop environmentally sociable alternatives to chemical processes in almost all steps of textile fiber processing. There are already some commercially effective claims, such as amylases for de sizing, celluloses and laccases for denim finishing, and proteases incorporated in detergent formulations. New enzymes with high specific movement, increased reaction speed, and acceptance to more extreme temperatures and $\mathrm{pH}$ could result in growth of continuous processes for bio scouring or bio finishing of cellulosic fibers. Progress of other processes in the future could also expand the use of enzymes on natural fibers into use on man-made fibers such as nylon and polyester. New and exciting enzyme claims are likely to bring benefits in other areas: less harm to the environment; greater efficiency \&lower costs; lower energy consumption; and the enhancement of a product's properties.

\section{Acknowledgments}

None.

\section{Conflicts of interest}

Author declares there is no conflict of interest in publishing the article.

\section{References}

1. Mojsov K. Enzyme scouring of cotton fabrics: a review. International Journal of Marketing and Technology (IJMT). 2012;2(9):256-275.

2. Rajendran R, Sundaram SK, Radhai R, et al. Bioscouring of cotton fabrics using pectinase enzyme its optimization and comparison with conventional scouring process. PakJ Biol Sci. 2011;14(9):519-525.

3. Li Y, Hardin ZR. Enzymatic scouring of cotton: effects on structure and properties. Cellulose. 1997;94.

4. Yonghua Li, Ian R Hardin. Enzymetic scouring of cotton: Effect on structure \& properties. Textile chemist \& colorist. 1997;29(8):71-76

5. El Shafie A, Fouda MM, Hashem M. One-step process for bio-scouring and peracetic acid bleaching of cotton fabric. Carbohydrate Polymers. 2009;78(2):302-308.

6. Oksanen T, Pere J, Paavilainen L, et al. Treatment of recycled kraft pulps with Trichoderma reesei hemicellulases and cellulases. J Biotechnol. 2000;78(1):39-48.

7. Tzanov Tzanko, Margarita Calafell, Georg M, et al. Bio-preparation of cotton fabrics. Enzyme and Microbial Technology. 2001;29(6-7):357362.

8. Sawada K, Tokino S, Ueda M, et al. Bioscouring of cotton with pectinase enzyme. Journal of the Society of Dyers and Colourists. 1998;114(11):333-336.

9. Hebeish A, Hashem M, Shaker N, et al. New development for combined bioscouring and bleaching of cotton-based fabrics. Carbohydrate Polymers. 2009;78(4):961-972.

10. Assignment point. Conventional Alkali Scouring and BioScouring on Cotton Knitted Fabric. 